\title{
English phrasal verbs potential in developing Russian first-year majors' foreign communicative competence
}

\author{
Dinara G. Vasbieva
}

DOI: $10.18355 /$ XL.2016.09.93-103

\begin{abstract}
The paper investigates research into the great potential of English phrasal verbs in developing first-year majors' foreign communicative competence in a non-language high school. Being one of the most dynamic and semantically rich groups of English verb lexicon in the modern English language, phrasal verbs attract students to English idiomaticity. Metaphors serve as must-have tools for teaching phrasal verbs to any ESL learner. Since understanding metaphors gives the best clue to the meanings of the phrasal verb, the ESL learner will be able to have a comprehensive understanding of the phrasal verbs under study and to remember them better. Fourteen first-year students majoring in International Finance at Financial University (Moscow) were trained in the training program "Learning English phrasal verbs through conceptual metaphors". A pre-test and an exit test were the main instruments used for the purpose of data collection. The performance-based pre-test was conducted before the training period and exit test was conducted after the training period to assess the participants. The very same set of students were made to do an exit test to assess their performance based on the training given to them in the usage of phrasal verbs. The $t$ test for correlated data and Sandler's $A$-test were done to find out, if at all, the training produced a positive effect on the ESL learners' results.

Key words: phrasal verbs, foreign language teaching, communicative competence, idiomatic expression, literal meaning, idiomatic meaning, idiomaticity
\end{abstract}

\section{Introduction}

Globalization of the world economy, changes in social and political life of the Russian Federation, the development and expansion of foreign economic relations with other countries, international economic integration, the possibility of getting a degree abroad and student exchange programs have led to some changes in education (Slukina \& Vasbieva, 2014). In the light of the development of international contacts and multi-faceted cooperation with foreign partners it is necessary to improve professional-level language proficiency approaching that of an educated native speaker (State educational standard ..., 2000).

However, the linguistic competence of Russian students coming close to near-native levels implies not only understanding lexical units and formal rules regarding their use in speech but also knowledge of an idiomatic expression (an idiom). To know idioms in a broad sense means to know a word of a foreign language, especially its compatibility with other words and its full semantic structure (Anichkov, 1947). It is important to lay a solid foundation for mastering idiomatic speech in the early stages of training, as the first course at a high school is a transition to teaching a foreign language for specific purposes.

Our experience of teaching English in non-language high school shows that first-year students have difficulty mastering lexical units that form the lexical side of foreign speech and have particular semantic and structural properties. These semantic 
units are phrasal verbs (PVs) that generate a large number of speech errors and probability of occurrence of communication failure due to interlingual and intralingual interference caused by a mismatch between the contents and meaning of these units: the structure of individual units of phrasal verbs has a semantic integrity but the meaning of PV is different from the literal meaning of the individual elements (Vasbieva, 2015).

\section{Review of Literature}

\subsection{Teaching Phrasal Verbs to Develop Key Competences}

The practical aim of foreign language teaching in the early stage in nonlanguage high schools is to develop linguistic communicative competence in reading, listening, speaking and writing so that students can communicate across cultures and reach an individual's language proficiency level (according to the Common European Framework of Reference for Languages). The CEFR divides general competences in knowledge (descriptive knowledge), skills, and existential competence with particular communicative competences in linguistic competence, sociolinguistic competence, and pragmatic competence. General and particular communicative competences are developed by producing or receiving texts in various contexts under various conditions and constraints. These contexts correspond to various sectors of social life that the CEFR calls domains. Four broad domains are distinguished: educational, occupational, public, and personal. However linguistic competence is certain to play an important role as it is the 'ideal' language system that makes it possible for speakers to produce and understand an infinite number of sentences in their language, and to distinguish grammatical sentences from ungrammatical sentences (Chomsky, 1965).

As phrasal verbs are most dynamic, productive, semantically rich group of English verb lexicon in present-day English language, they are extremely common, especially in spoken English, and are used more informally than their Latinate synonyms, e.g. use up vs. consume; gather together vs. assemble; find out vs. discover, blow up vs. explode, etc. When developed actively, phrasal verbs enrich the English lexicon in two ways:

1. involve all new verbs in the development of PVs

2. develop semantics of established language units

Some previous studies in Linguistics that have investigated PVs confirm the need for mastering this subsystem of English lexicon for effective communication (Bolinger, 1971; Hiltunen, 1999; Sroka, 1962; Berlizon, 1964; Bogdanova, 2006; Golubkova, 2002; etc.). PVs are widely accepted by native speakers during spoken communication and perform an essential function due to clarity and succinctness.

A well-defined strategy for teaching and learning PVs promotes the development of students' sociolinguistic competence along with linguistic competence as the suggested methodology forms students' skills to choose PVs in accordance with a communications act, i.e., communication situation, purposes, communicators' intentions and functions. In addition, teaching PVs plays a crucial role in developing students' compensatory competence which is an individual's ability to cope with difficult communication situations by means of compensatory strategies and skills due

XLinguae Journal, Volume 9 Issue 3, June 2016, ISSN 1337-8384 
to lack of linguistic and verbal resources (Koreneva, 2003). Learning and using synonyms, definitions in English when explaining the meaning of PVs contribute to the development of basic skills of compensatory competence such as ability to use synonyms and paraphrase.

Learning PVs is a key to development of students' pragmatic competence which comprises not only communicative and grammatical competences but also considers the appropriateness of language, taking sociocultural variables into account. According to many linguists (Berlizon, 1964; Smirnitskii, 1956; Kunin, 1996; Yatskovich, 2000; etc.), PVs are phraseological units included in composition of English phraseology. According to A.V. Kunin (1996: 308-309), phrasal verbs are a phraseological fusion consisting of a verb and post-verb (a specific unit which is neither a preposition, nor an adverb). Acquisition of PVs as phraseological units makes it possible not only to enrich the vocabulary but also to penetrate into native speakers' culture. Semantically transferred phraseological units are known to reflect long process of nation's cultural development, fix and pass cultural values and stereotypes from generation to generation. The problem of cultural peculiarities of phraseological units has been of much interest to modern linguists. V.N. Telia (1996), for instance, points out that the typical feature of phraseological units (PU) is their image-based motivation, which is directly connected with the nation world outlook. V.A. Maslova (2001) stresses the close relationships of PU with the native speakers' cultural and historical traditions. D.O. Dobrovolsky (1997) distinguishes between cultural-historical associations and national-cultural specific character of phraseological units.

\subsection{English Idiomaticity Through Phrasal Verbs}

An important argument in favour of choosing PVs as a means of an idiomatic speech and development of linguistic competence is the fact that unlike other parts of speech they have a variety of relationships with different classes of words and therefore there are a lot of collocations and interdependence of verb phrases and collocation structure meanings.

Phrasal verbs, which are often described as "idiomatic" — as being "idioms," in other words, are especially noteworthy. The words, that make up an idiomatic phrasal verb, lose their own meanings and, together, create a new one. Phrasal verbs vary in the strength of their idiomaticity. There are three degrees of idiomaticity: high idiomaticity, moderate idiomaticity, and low idiomaticity. For instance, the phrasal verb "call off," which means "cancel" or "postpone," is in "high idiomaticity" group: it would be difficult or impossible to guess its meaning from the knowledge of the meaning of its components. On the other hand, "bring in," which means "earn money," is moderately idiomatic; and "speed up," which means "suddenly accelerate," is in "low idiomaticity" group (it would be quite easy to guess its meaning from the knowledge of the meaning of its components). Phrasal verbs are generally considered informal. They are not appropriate in most written contexts and in some spoken ones. This is particularly so in the case of phrasal verbs such as "throw up" which have one-word equivalents ("vomit"). Many other phrasal verbs such as "take over" are, however, suitable in almost all contexts (Grammar glossary: 
phrasal verb, 2012). From the perspective of a learner of English as a foreign language (EFL), PVs are not only an important feature of English grammar whose degree of mastery reveals the command of lexicon and style. But, due to their heterogeneity and complexity, they are difficult to master and provide a vast potential for mistakes but they are also very complex and heterogeneous. According to Darwin and Grey (1999), many particle verbs have entirely idiomatic meaning although both

parts of the construction seem very familiar to the learners. This idiomaticity leads to avoidance or to errors because phrasal verbs constitute "a syntactic [and semantic] oddity in the language" to include the quotation by Darwin and Gray (1999). This is also the reason why phrasal verbs are difficult to describe. However these PVs might be a rich source of information on how the native speakers shape their worldview.

\subsection{Learning Phrasal Verbs through Conceptual Metaphors}

Phrasal verbs have meanings that are often difficult to remember, as they appear to have no connection with the words that they consist of (the verb and the particle). According to works of contemporary foreign linguists and methodologists (Lakoff \&Johnson,1980; Moon, 2005; etc.) many phrasal verbs are considered metaphorical, and if you understand the metaphors they use, their meanings will be easier to understand and remember. This statement is based on cognitive approach to language, which is, according to A.A. Kibrik (1994: 126), "persuasion that a linguistic form is reflection of cognitive structures, i.e., human consciousness, way of thinking and perception". In the book "Metaphors We Live By" authors G. Lakoff and M. Johnson (1980) show that their theory of metaphor within the cognitive sciences becomes central to the contemporary understanding of how people think and how they express their thoughts in language.

The examples below illustrate the same phrasal verb having both a literal and metaphorical meaning.

- $\quad$ The scientists dug up a dinosaur fossil (literal).

- He dug up some old photos that were in the back of his closet (metaphorical).

The first phrasal verb refers to a physical action, while the second one describes an action that is similar in some way to the first. For instance, when someone digs up photos, they find or discover them, and the activity seems similar to the way in which the scientists find a fossil which has been buried in the ground.

When the verb part of the PV is used metaphorically, this is usually quite obvious. But it is rather difficult to recognize the metaphorical use of the particle. However there is often a clear relationship between its literal meanings and metaphorical uses which is based on other conceptual metaphors, for example, direction. Lakoff and Johnson believe that many conceptual metaphors refer to position in space, for example, "up/down", "ahead/behind", "in/out", etc. One universal metaphor is the idea of 'up/high' and 'down/low' describing quantities. For instance, the idea 'up/high' refers to large quantities because when more things are added to a pile, it becomes higher:

- $\quad$ The price of oil has gone up by over 50 per cent in less than a year.

XLinguae Journal, Volume 9 Issue 3, June 2016, ISSN 1337-8384 
- The crime rate shows no signs of going down. (Macmillan Phrasal Verbs Dictionary Plus; 2005).

Another conceptual metaphor that occurs with 'up/high' and 'down/low' relates to status and power: powerful, important people are thought to be 'at the top' of an organization or society, while ordinary people without any power are 'at the bottom'. The idea 'up/high' refers to being powerful because the powerful person usually wins when he is physically on top of the other during the fight:

- He's been moved up to a more responsible job.

- We had to knuckle down and do what we were told.

- The rebellion was swiftly put down.

There are some other common metaphors and particles in PVs, which are conceptual metaphors (Moon 2005). Here are some of the examples:

Metaphors referring to time are ideas of 'ahead, back, behind, forward' describing time like a line that goes from the past (behind us: back, behind) to the future (in front of us: ahead, forward).

- I'm looking forward to hearing from you soon.

- The house dates back to the 18 th century.

Metaphors relating to problems: around, aside, off, over, round are based on the idea that we perceive problems and difficulties as if they were physical objects that get in our way. Some phrasal verbs have meanings to do with behaving as if problems did not exist or ignoring them. The metaphorical idea is that we go around or over the things that are in our way, or we push them farther away.

- We'll work round the problem somehow.

- $\quad$ They need to put aside their doubts.

- The moderator tried to smooth things over between the parties.

The metaphors under consideration which help understand and remember the meanings of idiomatic PVs, according to Lakoff and Johnson (1990: 396), are rooted in our physical and cultural experiences.

Thus, understanding metaphors, stipulating any given particle in the phrasal verb, promotes conceptualization of idiomatic phrasal verbs and good memory.

\section{Methodology}

\subsection{Research Design}

This is a diagnostic/experimental study as well as hypothesis testing in nature, to identify the relationship between the marks in the pre-test and exit test which are the two variables under consideration in order to predict or estimate the extent to which the training undergone by the participants was effective. The study design constructed here is based on the study of questions.

It is the framework of article, which stimulates what information, is to be collected, from which source and by which procedure.

Hypothesis: Null hypothesis is assumed that the two experiments will give same results. Value $\alpha$ has been fixed at 5\% level of significance.

Null Hypothesis $\mathrm{H}_{0}: \mu$ : experiment $\mathrm{A}=$ experiment $\mathrm{B}$.

Alternative Hypothesis $\mathrm{H}_{\alpha} \mu$ : experiment $\mathrm{A}$ =experiment $\mathrm{B}$.

Data collection: The present study is based on primary data.

Analysis of Data: Data has been analysed with the Sandler A test and T statistics non parametric tests. Interpreting and Reporting Finally the researchers 
have to prepare the report of what has been done by them in the form of conclusion.

Problems Encountered by Researchers and scope for further research:

The $t$ test for correlated data and $A$ test developed by Joseph Sandler have been used by the researcher as correlated samples are employed and hypothesized mean difference is taken as Zero, i.e. $\mathrm{H}_{0}: \mu_{\mathrm{D}}=0$

$$
\begin{gathered}
t=\frac{\sum D}{\sqrt{\frac{n \sum D^{2}-(\Sigma D)^{2}}{n-1}}} \\
A=\frac{\text { The Sum of squares of the difference }}{\text { The Squares of the sum of the difference }}=\frac{\Sigma D^{2}}{(\Sigma D)^{2}}
\end{gathered}
$$

We have the computed values of $t$ and $A$, which then have been compared with its corresponding table values for drawing inference concerning acceptance or rejection of null hypothesis. As if the calculated value of $t$ or $A$ is equal or less than the table value, $t$ or $A$ statistics is considered significant where upon researcher can reject $\mathrm{H}_{0}$ and accept $\mathrm{H}_{\alpha}$. But if the calculated values of $t$ or $A$ is more than its table value, then $t$ or $A$ statistics is taken as insignificant and accordingly researcher can accept $\mathrm{H}_{0}$.

\subsection{Population and Sample of the Study}

Fourteen Russian speaking first-year full-time students majoring in International Finance at Financial University under the Government of the Russian Federation took part in the study. The subjects had already had eleven years of formal instruction in EFL at the rate of about four hours per week at a secondary school. For the pre-test and exit test, students need testing on what they are learning in the classroom in order to ensure student growth is measured accurately.

\subsection{The Instruments of the Study}

The main instruments used for the purpose of data collection are a pre-test as well as an exit test.

The participants' assessments were based on their performance in the pretest before the training period. After they had undergone the three-month training, they were given the exit test. The same questions were used both in the pre-test and the exit test to increase the validity of the tests. The students concerned were asked to write on the following topics:

1 Write a dialogue between your favourite celebrities with as many phrasal verbs as possible.

2 Write a paragraph describing the most colorful event that you particularly enjoyed with phrasal verbs of your choice.

To achieve and make the students interested in the use of phrasal verbs, the researcher had chosen questions to ask about students' personal experience. As to the first question, the students had a wide variety in the choice of their favourite celebrities. Regarding the second one, the students were interested in describing thoughtfully the most colorful event that they particularly enjoyed. The papers were assessed, the prime importance being given to the use of phrasal verbs. The marks obtained in the pre-test and exit test were compared to find out, if at all the training has had much to contribute to improve performance and enhance the fluency of the ESL learner.

XLinguae Journal, Volume 9 Issue 3, June 2016, ISSN 1337-8384 


\section{Results and Discussion}

The purpose of this research paper was to implement an analysis that would cover the relationship between the marks in the pre-test and exit test which are the two variables considered in order to predict or evaluate the extent to which the training undergone by the participants was effective. The $t$ test for correlated data and Sandler's $A$-test were done to find out, if at all, the training produced a positive effect on the ESL learners' results.

The null hypothesis $\left(\mathrm{H}_{0}\right)$ in this case is that there is no difference between the marks in the pre-test and exit test. The data are set out in Table 1.

\subsection{Using the t test for correlated data}

\begin{tabular}{|c|c|c|}
\hline \multirow{2}{*}{ Students } & \multicolumn{2}{|c|}{ Results (scores) } \\
\cline { 2 - 3 } & Pre-test & Exit test \\
\hline A & 80 & 82 \\
\hline B & 82 & 82 \\
\hline C & 75 & 68 \\
\hline D & 70 & 80 \\
\hline E & 78 & 70 \\
\hline F & 65 & 75 \\
\hline G & 68 & 70 \\
\hline H & 69 & 60 \\
\hline I & 57 & 65 \\
\hline J & 60 & 72 \\
\hline K & 70 & 75 \\
\hline L & 68 & 78 \\
\hline M & 75 & 70 \\
\hline N & 74 & \\
\hline
\end{tabular}

Table 1: Results of the Pre-Test and Exit Test

The difference of the two sets of data can be estimated using the $t$ test for correlated means.

$t$ is given by the formula:

$$
t=\frac{\sum D}{\sqrt{\frac{n D^{2}-\left(\sum D\right)^{2}}{n-1}}}
$$




\begin{tabular}{|c|c|c|c|c|}
\hline \multirow[t]{2}{*}{ Students } & \multicolumn{2}{|c|}{ Results (scores) } & \multirow[t]{2}{*}{$D$} & \multirow[t]{2}{*}{$D^{2}$} \\
\hline & Pre-test & Exit test & & \\
\hline $\mathrm{A}$ & 80 & 82 & 2 & 4 \\
\hline $\mathrm{B}$ & 82 & 80 & -2 & 4 \\
\hline $\mathrm{C}$ & 75 & 82 & 7 & 49 \\
\hline $\mathrm{D}$ & 70 & 68 & -2 & 4 \\
\hline $\mathrm{E}$ & 78 & 80 & 2 & 4 \\
\hline $\mathrm{F}$ & 65 & 70 & 5 & 25 \\
\hline $\mathrm{G}$ & 68 & 75 & 7 & 49 \\
\hline $\mathrm{H}$ & 69 & 70 & 1 & 1 \\
\hline I & 57 & 60 & 3 & 9 \\
\hline $\bar{J}$ & 60 & 65 & 5 & 25 \\
\hline $\mathrm{K}$ & 70 & 72 & 2 & 4 \\
\hline $\mathrm{L}$ & 68 & 75 & 7 & 49 \\
\hline $\mathrm{M}$ & 75 & 78 & 3 & 9 \\
\hline $\mathrm{N}$ & 74 & 70 & -4 & 16 \\
\hline$n=14$ & & & $D=36$ & $\sum D^{2}=252$ \\
\hline
\end{tabular}

Table 2: Results of the Pre-Test and Exit Test: Computation

Note. $\mathrm{D}=$ the difference between each student's two scores; $\mathrm{n}=$ the number of students.

Substituting our data from Table 2

$$
t=\frac{36}{\sqrt{\frac{14(252)-(36)^{2}}{13}}}=\frac{36}{\sqrt{\frac{3528-12.96}{13}}}=\frac{36}{\sqrt{171.69}}=2.74 \quad 5 \%(\mathrm{t}=2.16)
$$

Degrees of freedom is given by the formula:

$$
\mathrm{df}=n-1=14-1=13
$$

The obtained value of $t=2.74$ exceeds the critical value at $5 \%$ level $(t=2.16)$. The researcher should therefore reject the null hypothesis $\left(\mathrm{H}_{0}\right)$ and conclude that the training had a positive effect on ESL learners.

\subsection{Using Sandler's A Statistic}

A simple alternative to $t$ for correlated data was suggested by Sandler (1955). Sandler's $A$ is given by the formula:

$$
A=\frac{T \text { he sum of squares of the difference }}{\text { The squares of the sum of the difference }}=\frac{\Sigma D^{2}}{(\Sigma D)^{2}}
$$

Substituting our data from Table 2 above: 
Since $\mathrm{H}_{\alpha}$ in the given problem is one-sided, one tailed test has been applied. Accordingly, at $5 \%$ level of significance, the table value of $A$-statistic for $(n-1)$ or (14$1)=13$ degrees of freedom in the given case is 0.368 (as per table of $A$-statistic). The calculated value of $A$ is 0.195 , which is lower than this table value and as such $A$ statistic is significant and accordingly $\mathrm{H}_{0}$ should be rejected. This has resulted in the inference that there is a positive relationship of statistical significance between the two variables (the marks scored by the students in the pre-test and exit test respectively) as proposed by the alternative hypothesis. As a result, it is concluded that the findings of the present study well demonstrated the efficiency of the training. Our conclusion is precisely the same as we would arrive at using the $t$ test for correlated data.

\section{Conclusion}

In conclusion, teaching phrasal verbs, which are one of the most distinctive and creative features of the modern English language, equips first-year majors with skills and abilities to use the productive vocabulary in speech for implementing communication tasks and develop foreign communicative competence through its key components: linguistic, socio-linguistic, socio-cultural and compensatory competences.

Teaching phrasal verbs through the systematic process make it possible to develop students' linguistic competence as:

- $\quad$ learning phrasal verbs through conceptual metaphors can develop and improve students' skills and abilities to use the productive vocabulary in speech for implementing communication tasks through knowledge of definitions and meanings of PVs in English

- being familiar with the term "phrasal verb" will provide students with theoretical knowledge of one of subsystems in English lexicon

- $\quad$ knowing features of phrasal verbs will make it possible for students to identify them in texts and distinguish them from regular verbs plus a preposition or adverb

- $\quad$ knowing structures of phrasal verbs will make it possible to produce syntactic forms in compliance with language standards

- developing speaking skills due to the use of phrasal verbs

The $t$ test for correlated data and Sandler's $A$-test proved that the training program "Learning English phrasal verbs through conceptual metaphors" had a positive effect on the ESL learners as they had a comprehensive insight into the use of the studied phrasal verbs.

\section{Acknowledgments}

The work is performed according to the Program of Development of Federal StateFunded Educational Institution of Higher Education "Financial University under the Government of the Russian Federation" for 2020.

\section{Bibliographic references}

ANICHKOV, I.E. 1964. Idiomaticity of Idioms and Idiomaticity of Idiomatisms (on theory of collocations) // Phraseology problems. M.; L.: Nauka, pp. 37-56. 
BERLIZON, S.B. 1964. English Verbal Collocations. - M.; L.: Prosveschenie.

BOGDANOVA, S.Yu. (2006). Conceptualisation of Space in the Mirror of English Phrasal Verb. Irkutsk. Irkutsk state linguistic university.

BOLINGER, D. 1971. The phrasal Verb in English. Cambridge, Mass.: Harvard University Press.

CHOMSKY, N. 1965. Aspects of the Theory of Syntax. Cambridge, MA: MIT Press.

DARWIN, C., and GRAY, L. 1999. Going after the phrasal verb: An Alternative Approach to Classification. TESOL Quarterly, pp. 65-83. http://dx.doi.org/10.2307/3588191

DOBROVOLSKY, D.O. 1997. National Cultural Peculiarities in Phraseology / D.O.Dobrovolsky// Voprosy Yazykoznaniya, 6, pp. 37-48.

GOLUBKOVA, E.E. 2002. Phrasal Verbs of Movement (cognitive aspect). - M.: GEOS.

GRAMMAR GLOSSARY: PHRASAL VERB. 2012. Retrieved from http://flesl.net/Grammar/Grammar_Glossary/phrasal_verb.php

HILTUNEN, R. 1999. "Verbal Phrases and Phrasal Verbs in Early Modern English", in Collocational and Idiomatic Aspects of Composite Predicates in the History of English, ed. by L.J. Brinton \& M. Akimoto, Amsterdam, Benjamins, pp. 133-165.

KIBRIK, A. A. 1994. Cognitive Research on Discourse // Voprosi Yazikoznaniya, n. 5, pp.126-139.

KORENEVA, M.R. 2003. Methods of Forming Students' Speaking Compensatory Skills $\left(2^{\text {nd }}\right.$-year, French language). Ulan-Ude.

KUNIN, A.V. 1996. The Course of Modern English Phraseology. M.: Visshaya shkola: Dubna: Fenix.

LAKOFF, G. \& JOHNSON, M. 1990. Metaphors We Live By // Theory of Metaphor. M., pp. 387-415.

MACMILLAN PHRASAL VERBS PLUS. 2005. Oxford: Bloomsbury Publishing Plc. MASLOVA, V.A. 2001. Language Cultural Studies/V.A.Maslova. - Moscow: Academia.

MOON, R. 2005. Metaphor and Phrasal Verbs / R. Moon // Macmillan Phrasal Verbs Plus. Bloomsbury Publishing Plc., pp. 5-9.

SANDLER, J. 1955. A Test of the Significance of the Difference Between the Means of Correlated Measures, Based on a Simplification of Student's r. Brit. 1. Psychol., pp. 225-226.

SLUKINA, G.V. \& VASBIEVA, D.G. 2014. English Phrasal Verbs as a Means of Development of Students' Cross-Cultural Professional Communicative Competence. // Fundamental and Applied Research Studies of the Economics Cooperative Sector, n.1, pp. 207-211. ISBN: 2076-9288

SMIRNITSKII, A.I. 1956. Lexicology of English. M.: Literature in foreign languages. SROKA, K. 1962. "Critique of the Traditional Syntactic Approach to Adverb / Preposition Words in Modern English", Bulletin de la société polonaise de linguistiqhe.

SROKA, K. 1972. The Syntax of English Phrasal Verbs, The Hague, Mouton.

STATE EDUCATIONAL STANDARD for High Professional Education: Area of Qualifications "620100 - Linguistics and Intercultural Communication". Moscow.

TELIA, V.N. 1996. Russian Phraseology. Semantic, Pragmatic, and Linguocultural Aspects. Moscow, Russia: Yazyki russkoi kultury.

VASBIEVA, D.G. 2015. Teaching Strategy on Learning of English Phrasal Verbs by Economics Major Students in Russia. In: XLinguae, vol. 8, n.3, pp. 57-65. http://dx.doi.org/10.18355/XL.2015.08.03.57-65

YATSKOVICH, I.A. 2000. Cognitive Aspect of English Phrasal Verbs Translation in

XLinguae Journal, Volume 9 Issue 3, June 2016, ISSN 1337-8384 
Dictionary. (Candidate's dissertation). Retrieved from http://www.dissercat.com/content/kognitivnyi-aspekt-slovarnogo-perevodaangliiskikh-frazovykh-glagolov-0\#ixzz3j9InKphB

Words: 4165

Characters: 26663 (14,81 standard pages)

Assoc. Prof. Dinara Giniyatullovna Vasbieva, PhD.

Department "Foreign Languages - 4"

Financial University under the Government of the Russian Federation Leningradsky prospect 49

125993 Moscow

Russia

dinara-va@list.ru 